\title{
Social Work Grand Challenges and the U.N. Sustainable Development Goals: Linking Social Work and Women's Health
}

\author{
Annalise John, MSW \\ Address: 395 South 1500 East \#111, UT \\ Tel: 801-581-6192Ｅ-mail: annalise.j@comcast.net \\ Elizabeth Gamarra, MSW \\ Address: 395 South 1500 East \#111, UT \\ Tel: 801-462-5654_E-mail: egamarra15@yahoo.com
}

\begin{abstract}
Melissa Bird, MSW
Missy is at the School of Social Work, University of Southern California 669 W 34th St, Los Angeles, CA 90089

TeL: (714) 343-8601 E-mail: birdm@usc.edu
\end{abstract}

Rachel L. Wright PhD, MSW

Department of Social Work, Appalachian State University, Boone, NC

ASU Box 32155

331 Edwin Duncan Hall, Boone, NC 28608-2155

Tel: (801) 787-2562 E-mail: wrightrl@appstate.edu

Caren J. Frost PhD, MPH

Address: 395 South 1500 East \#111, UT

Tel: 801-581-5287 E-mail: caren.frost@socwk.utah.edu 
Received: October 18, 2016 Accepted: December 22, 2016 Published: December 26, 2016

doi:10.5296/ ijsw.v3i2.10176

URL: http://dx.doi.org/10.5296/ijsw.v3i2.10176

\begin{abstract}
The health of women is a crucial component to family and community wellbeing. However, social work scholars have not been very engaged in research pertaining to the health needs of women. With the Grand Challenges of Social Work becoming a major element for national discussion and with the revision of the UN Sustainable Development Goals (SGD) in 2015, we wondered how connected the 12 Grand Challenges and the 17 SDGs were. We searched the social work literature from 2005 to present to identify what salient publications were available about women's health and then connected them to the current themes of the Grand Challenges and SDGs. There are no more articles to review in the social work literature. Using a feminist social work framework, we summarize the topics covered in these articles and define a call to action for more scholarly work on women's health in the context of current national and global conversations about this social justice issue.
\end{abstract}

Keywords: Grand challenges for social work, UN sustainable developmental goals, Women's health, Global social work

\title{
1. Introduction
}

Health is both a human rights and social justice issue (Craig et al., 2013). Although health affects all people, women in particular are more vulnerable to poor health than men (Pillai \& Maleku, 2013). Across the globe, women's health is continually challenged, which is evidenced by the existence of practices such as sex trafficking, female genital mutilation, and intimate partner violence, as well as a lack of adequate funding for health and social service programs. In addition to these issues, literature shows poor health outcomes for women in the areas of maternal, reproductive, and mental health even though women are not genetically predisposed to having poorer physical and/or mental health than men. Rather it is social determinants and continued gender inequality that have been found to be the principal correlates of health (Craig et al., 2013; Pandey et al., 2012). Feminism and social work started by feminist social actions lead by women from a number of communities for purposes of enhancing well being and status in society (Eyal-Lubling \& Krumer-Nevo, 2016). Feminism has been woven into social work theory and practice to contribute to feminist scholarship. Furthermore, social work in relation to women's health provides a holistic integrative lens of former and current efforts.

\subsection{U.N. Sustainable Development Goals}

In 2015, the United Nations launched the 2030 Agenda for Sustainable Development, also known as the Sustainable Development Goals (SDGs)--these goals are being used to redefine social and environmental determinants of health worldwide. These 17 global goals have specific purposes that governments are expected to participate in by becoming accountable as they establish national frameworks to meet each goal (Ludwig, 2016). These goals consist of no poverty; zero hunger; good health and well-being; quality education; gender equality; 
clean water and sanitation; affordable and clean energy; decent work and economic growth; industry, innovation and infrastructure; reduced inequalities; sustainable cities and communities; responsible consumption and production; climate action; life below water; life on land; peace, justice and strong institutions; and partnerships for the goals (Ludwig, 2016). These goals can be linked to the global expectations for developing education, policy, practice, and research in higher education--social work is in a position to assist in meeting the goals on the macro, mezzo, and micro levels.

\subsection{The Grand Challenges for Social Work}

In 2016, the American Academy of Social Work and Social Welfare launched the 12 Grand Challenges for Social Work; a call to action and social justice agenda focused on identifying and addressing current critical social justice issues (Williams, 2016). Each challenge represents a broad yet tangible concept relevant to the roles and skills of social workers. In fact, each challenge connects to people's wellbeing and progress for a more just society. They consist of ensuring healthy development for all youth; closing the health gap, stopping family violence; advancing long and productive lives; eradicating social isolation; ending homelessness; creating social responses to a changing environment; harnessing technology for social good; promoting smart decarceration; reducing extreme economic inequality; building financial capability for all; and achieving equal opportunity and justice (Williams, 2016). These challenges define the way forward for social work activities in practice, education, research, and policy for the 21 st Century.

\subsection{Connection of Grand Challenges and the SDGs}

Over the past several years there has been an increased effort to recognize women's health status as an important issue in social work (Bird et al., 2016; Wright et al., 2015; Jang, 2009). Several of the Grand Challenges specifically address the need to better support women. While the Grand Challenges address the needs of women in the United States, the issues highlighted are applicable to women around the globe. The "global women's movement" (NASW, n.d.; Alzate, 2009) sheds light on such elements yet the status of women in relation to men remains unequal. The National Association of Social Work (NASW) recognizes such inequality and is advancing policy and practices to protect and improve the wellbeing of all women. Overall, the Grand Challenges for Social Work and the SDGs can be used to stimulate action on a global scale and include several goals that could empower women throughout the world. These social justice issues can be addressed by the discipline of social work through development and implementation of practical and appropriate interventions; however, more often social work has left these activities for other disciplines to solve.

The United Nations' Sustainable Development Goals (SDGs) were adopted in mid-2015 with the purpose of "ending poverty, fighting inequality and among others, tackling climate change by 2030" (United Nations, n.d.). According to Jayasooria (2016), the global agenda and goals have relevancy and applicability to social work practice. In fact, social work addresses human rights and environmental concerns in a number of political and systemic structures. Furthermore, the Grand Challenges are an additional layer linked to the SDGs highlighting significant societal issues relevant to women's health, which are not independent of other variables. Addressing issues such as poverty, social violence, and education, these Grand Challenges can have a direct economic impact on women's health and status. As we 
reviewed these Grand Challenges, we identified six that could have the biggest impact on health for women: closing the health gap, stopping family violence, advancing long and productive lives, ending homelessness, reducing extreme economic inequality, and achieving equal opportunity and justice.

According to the International Federation of Social Workers (IFSW) (2012), social work has actively participated in a number of significant efforts to increase the quality of life for women. These factors include the delivery of health and mental health care services, community-based violence interventions, access to education, employment and efforts to increase the number of women in decision-making positions. Additionally, promoting both sexual and reproductive rights are essential pieces to such efforts for purposes of improving the health status of women. A 2009 study highlighted the relevancy of sexual and reproductive rights as large pieces of the foundation and practice of social work stressing a framework that should focus on health needs that stem from a "global feminist movement" (Alzate, 2009).

"Women's rights are ultimately human rights," as noted by recently by Secretary of State Clinton. The link between these two concepts is a core value of the social work profession historically and internationally (IFSW, 2012). Social work's commitment to the welfare and wellbeing of clients and social justice requires attention to women's rights. In relation to ethics and practice, social work must also seek to capitalize on the strengths and contributions of women and girls. This article reviews the social work scholarly literature to better understand what social workers are publishing regarding global women's health and which Grand Challenges in Social Work these publications address.

\section{Theoretical Framework}

The term ecofeminism developed during the 1970s and 1980s when several social movements were taking place, specifically the feminist, peace, and ecology movements (Mies \& Shiva, 1993). During this period of time there were many protests occurring against environmental destruction. The first ecofeminist conference "Women and Life on Earth" took place in the 1980s following the partial nuclear meltdown at Three Mile Island in the U.S. (Mies \& Shiva, 1993). The discussions at the conference created a more concrete understanding of ecofeminism as a theoretical paradigm for understanding the natural world and the manmade systems of oppression therein.

Ecofeminism recognizes the interconnectedness between ecology, peace, feminism, and health (Mies \& Shiva, 1993). This type of feminism suggests that every living entity holds integrity (Mies \& Shiva, 1993). Therefore, how women and other marginalized groups are treated is connected to the ways in which the natural environment is treated (Warren \& Erkal, 1997). This type of feminism claims, "nature is a feminist issue" (Warren, 2000, p. 1), due to the fact that the same power systems that oppress women also oppress the environment in which they live. Mies and Shiva (1993) state that the system of power, namely patriarchy, depends on dominating multiple systems in order to stay in power and to unjustly dominate people of color, children, the poor, and all other groups that are less powerful (Warren, 2000). Ecofeminism is based on the connectedness of these multiple systems. The connections between health, women, children, socioeconomic status, and the environment can be seen in lower, middle and high income countries. For example, women in some lower income 


\section{MInstitute Macrothink}

International Journal of Social Work

ISSN 2332-7278

2016, Vol. 3, No. 2

countries spend several hours a day cooking with biomass products in inadequately ventilated areas, causing them to be exposed to high levels of indoor pollution (Warren, 2000). This exposure poses a serious health risk, which illustrates that the health of women, especially those in poor communities, is disproportionately affected by damaging environmental practices (Warren, 2000). This disparity is seen in middle and high income countries as well. For example, after the Exxon Valdez oil spill, it was found that women living in some areas of Alaska suffered miscarriages at a much higher rate than average (Warren, 2000).

In her book, Ecofeminist Philosophy, Warren claims that in order to understand the oppression of women it is essential to understand nature as well (2000). She states that untangling the interconnections between subordinate groups is best done through feminist approaches using gender as the lens through which we analyze these connections. Warren points out that the use of gender analysis does not mean that gender oppression is more important than any other form of oppression; it is simply a lens that is able to reveal "important features of interconnected systems of human domination" (2000, p. 2). Ecofeminism allows for a wide range of social and environmental issues to be addressed and challenges the systems, which oppress both humans and nature (Mortimer-Sandilands, 1999). This lens is a good fit for developing a clearer understanding about how the SDGs and the Grand Challenges in Social Work are connected, as well as how social work is addressing issues around women's health in the scholarly literature. Table 1 highlights how the SDGs and the Grand Challenges in Social Work that connect to women's health are linked.

Table 1. Grand challenges in social work $(n=6)$ and the U.N.'s sustainable development goals $(n=9)$ linking to women's health

\begin{tabular}{|c|c|}
\hline Grand Challenges in Social Work & U.N. Sustainable Development Goals \\
\hline Close the Health Gap (CHG) & Good Health; Well-being; Quality Education \\
\hline End Family Violence (EFV) & Good Health and Well-being; Gender Equality \\
\hline $\begin{array}{l}\text { Advance Long and Productive Lives } \\
\text { (ALPL) }\end{array}$ & $\begin{array}{l}\text { Zero Hunger; Good Health and Well-being; } \\
\text { Quality Education; Clean Water and Sanitation; } \\
\text { Affordable and Clean Energy }\end{array}$ \\
\hline End Homelessness (EH) & No Poverty \\
\hline $\begin{array}{l}\text { Reduce Extreme Economic Inequality } \\
\text { (REEI) }\end{array}$ & No Poverty; Reduced Inequalities \\
\hline $\begin{array}{l}\text { Achieve Equal Opportunity and Justice } \\
\text { (AEOJ) }\end{array}$ & $\begin{array}{l}\text { Gender Equality; Decent Work and Economic } \\
\text { Growth; Peace, Justice, and Strong Institutions }\end{array}$ \\
\hline
\end{tabular}

\section{Methods}

A literature search was conducted using Google Scholar, JSTOR, Academic Search Premier, and Ebsco, using the terms: "Global" AND "Women" AND "Health." The search was limited to journals related to the field of social work. The rationale for excluding literature from other fields of study was to only include literature that was most relevant to the Grand Challenges of 


\section{Macrothink}

International Journal of Social Work

ISSN 2332-7278

2016, Vol. 3, No. 2

Social Work and better determine what is being published in the scholarly social work literature. In order to focus on current sources, articles published between the years 2006 and 2016 were included. Forty articles were identified initially and analyzed to assess their relevance to the following six Grand Challenges of Social Work: closing the health gap, stopping family violence, advancing long and productive lives, ending homelessness, reducing extreme economic inequality, and achieving equal opportunity and justice. Thirteen articles were excluded from analysis because they were commentaries only and/or did not link directly to one of the six Grand Challenges - thus 27 articles were analyzed for this manuscript (see Table 2). The topic areas linked to the Grand Challenges and the social work articles connected to them are explored below. Articles may be discussed in more than one Grand Challenge area, because topic are not discrete. There are no more articles or literature identified to review.

Table 2. Articles and links to social work grand challenges $(n=26)$

\begin{tabular}{|c|c|c|}
\hline Author & Relevant Grand Challenges & Methods/Populations \\
\hline Alzate, M. M. (2009) & $\begin{array}{ll}\text { - } & \text { CHG } \\
\text { - } & \text { ALPL } \\
\text { - } & \text { AEOJ }\end{array}$ & $\begin{array}{l}\text { - Literature } \\
\text { emphasizing the impact of } \\
\text { reproductive health and } \\
\text { rights of women. }\end{array}$ \\
\hline $\begin{array}{l}\text { Craig, S. L., Bejan, R., \& } \\
\text { Muskat, B. (2013) }\end{array}$ & $\begin{array}{ll}\text { - } & \mathrm{AEOJ} \\
\text { - } & \mathrm{CHG}\end{array}$ & $\begin{array}{l}\text { - Quantitative study } \\
\text { with hospital based social } \\
\text { workers between ages } 22 \\
\text { and } 64 \text {. }\end{array}$ \\
\hline $\begin{array}{l}\text { Fawcett, B., \& Reynolds, } \\
\text { J. (2009) }\end{array}$ & $\begin{array}{ll}\text { - } & \text { ALPL } \\
\text { - } & \text { AEOJ }\end{array}$ & $\begin{array}{l}\text { - Examining the } \\
\text { perceptions of mental } \\
\text { health field; fostering } \\
\text { community } \\
\text { building. }\end{array}$ \\
\hline $\begin{array}{l}\text { Grote, N. K., Bledsoe, S. } \\
\text { E. \& Larkin, J (2007). }\end{array}$ & $\begin{array}{ll}\text { - } & \text { ALPL } \\
\text { - } & \text { GHG } \\
\text { - } & \text { AEOJ }\end{array}$ & $\begin{array}{l}\text { - Quantitative study } \\
\text { with women } 18 \text { years or } \\
\text { older. }\end{array}$ \\
\hline $\begin{array}{l}\text { Grote, N. K., Zuckoff, A., } \\
\text { Swatz, H., Bledsoe, S. E., } \\
\text { \& Geibel, S. (2007). }\end{array}$ & $\begin{array}{ll}\text { - } & \text { ALPL } \\
\text { - } & \text { REEI } \\
\text { - } & \text { AEOJ }\end{array}$ & $\begin{array}{l}\text { - Literature exploring a } \\
\text { therapeutic psychosocial } \\
\text { engagement strategy. }\end{array}$ \\
\hline Herbst, C. M. (2012) & $\begin{array}{ll}\text { - } & \text { ALPL } \\
\text { - } & \text { REEI } \\
\text { - } & \text { AEOJ }\end{array}$ & $\begin{array}{l}\text { - Quantitative study } \\
\text { using the DDB Worldwide } \\
\text { survey data; women } 18 \text { - } 64 \\
\text { years old. }\end{array}$ \\
\hline Hodge, D. R. (2014) & $\begin{array}{ll}\text { - } & \text { ALPL } \\
\text { - } & \text { AEOJ }\end{array}$ & $\begin{array}{l}\text { - Literature examining } \\
\text { human, labor and sex }\end{array}$ \\
\hline
\end{tabular}




\section{Macrothink}

International Journal of Social Work

ISSN 2332-7278

2016, Vol. 3, No. 2

\begin{tabular}{|c|c|c|}
\hline & & trafficking. \\
\hline Jang, S. J. (2009) & $\begin{array}{ll}\text { - } & \text { ALPL } \\
\text { - } & \text { AEOJ }\end{array}$ & $\begin{array}{lr}\text { - Literature } & \text { review; } \\
\text { feminist } & \text { framework; } \\
\text { government policy making }\end{array}$ \\
\hline $\begin{array}{l}\text { Jayasooria, } \\
\text { D. }(2016)\end{array}$ & $\begin{array}{ll}\text { - } & \mathrm{CHG} \\
\text { - } & \mathrm{ALPL} \\
\text { - } & \mathrm{AEOJ}\end{array}$ & $\begin{array}{l}\text { - Literature exploring } \\
\text { social work practice and } \\
\text { SDG's in Malaysia. }\end{array}$ \\
\hline Jungari, S. B. (2015) & $\begin{array}{ll}\text { - } & \mathrm{CHG} \\
\text { - } & \mathrm{EGV} \\
\text { - } & \mathrm{ALPL} \\
\text { - } & \mathrm{AEOJ}\end{array}$ & $\begin{array}{l}\text { - Literature examining } \\
\text { the prevalence and practice } \\
\text { of Female Genital } \\
\text { Mutilation. }\end{array}$ \\
\hline Klomegah, R. (2008) & $\begin{array}{ll}\text { - } & \text { EFV } \\
\text { - } & \text { ALPL } \\
\text { - } & \text { AEOJ }\end{array}$ & $\begin{array}{l}\text { - Health survey data; } \\
\text { married women; exploring } \\
\text { wife abuse. }\end{array}$ \\
\hline $\begin{array}{l}\text { Macy, R. J., Ferron, J., \& } \\
\text { Crosby, C. (2009) }\end{array}$ & $\begin{array}{ll}\text { - } & \text { RFV } \\
\text { - } & \text { ALPL } \\
\text { - } & \text { AEOJ }\end{array}$ & $\begin{array}{l}\text { - Literature examining } \\
\text { health outcomes related to } \\
\text { partner violence } \\
\text { victimization. }\end{array}$ \\
\hline $\begin{array}{l}\text { Orme, J., \& Ross-Sheriff, } \\
\text { F. (2015) }\end{array}$ & $\begin{array}{ll}\text { - } & \text { LPL } \\
\text { - } & \text { EOJ }\end{array}$ & $\begin{array}{l}\text { - Literature examining } \\
\text { anti-sex } \\
\text { policies programs and } \\
\text { services. }\end{array}$ \\
\hline $\begin{array}{l}\text { Pandey, S., Lama, G., \& } \\
\text { Lee, H. (2011) }\end{array}$ & $\begin{array}{ll}\text { - } & \mathrm{CHG} \\
\text { - } & \mathrm{EFV} \\
\text { - } & \mathrm{ALPL} \\
\text { - } & \mathrm{AEOJ}\end{array}$ & $\begin{array}{l}\text { - Quantitative national } \\
\text { sample of previously } \\
\text { pregnant women in Nepal. }\end{array}$ \\
\hline $\begin{array}{l}\text { Pandey, S., Lin, Y., } \\
\text { Collier-Tenison, S., \& } \\
\text { Bodden, J. (2012) }\end{array}$ & $\begin{array}{ll}\text { - } & \text { CHG } \\
\text { - } & \text { EFV } \\
\text { - } & \text { ALPL } \\
\text { - } & \text { AEOJ }\end{array}$ & $\begin{array}{l}\text { - Quantitative study of } \\
\text { blind women who had } \\
\text { given birth in the last } 5 \\
\text { years. }\end{array}$ \\
\hline $\begin{array}{l}\text { Park, J. M., Fertig, A. R., } \\
\text { \& Metraux, S. (2011) }\end{array}$ & $\begin{array}{ll}\text { - } & \mathrm{CHG} \\
\text { - } & \mathrm{ALPL} \\
\text { - } \mathrm{EH} \\
\text { - } \mathrm{REEI} \\
\text { - } \mathrm{AEOJ}\end{array}$ & $\begin{array}{l}\text { - Quantitative } \\
\text { longitudinal study on } \\
\text { Fragile Families and Child } \\
\text { Wellbeing data. }\end{array}$ \\
\hline Phillips, R. (2009) & - $\mathrm{CHG}$ & - Literature examining \\
\hline
\end{tabular}




\begin{tabular}{|c|c|c|}
\hline & $\begin{array}{ll}\text { - } & \text { ALPL } \\
\text { - } & \text { REEI } \\
\text { - } & \text { AEOJ }\end{array}$ & $\begin{array}{l}\text { food insecurity, women's } \\
\text { health, and feminist } \\
\text { frameworks. }\end{array}$ \\
\hline $\begin{array}{l}\text { Pillai, V. K., \& Maleku, A. } \\
\text { (2013) }\end{array}$ & $\begin{array}{ll}\text { - } & \text { CHG } \\
\text { - } & \text { ALPL } \\
\text { - } & \text { REEI } \\
\text { - } & \text { AEOJ }\end{array}$ & $\begin{array}{l}\text { - Quantitative study; } \\
\text { World Bank data from } \\
\text { 1980-2010 on five } \\
\text { indicators of health }\end{array}$ \\
\hline Price, S. K. (2010) & $\begin{array}{ll}\text { - } & \text { ALPL } \\
\text { - } & \text { CHG } \\
\text { - } & \text { AEOJ }\end{array}$ & $\begin{array}{l}\text { - Quantitative } \\
\text { community-based data } \\
\text { from self-referred low } \\
\text { income women. }\end{array}$ \\
\hline $\begin{array}{l}\text { Rosen, D., Warner, L. A., } \\
\text { \& Tolman, R. M. (2006) }\end{array}$ & $\begin{array}{ll}\text { - } & \text { ALPL } \\
\text { - } & \text { REEI } \\
\text { - } & \text { CHG } \\
\text { - } & \text { REEI }\end{array}$ & $\begin{array}{l}\text { - Quantitative } \\
\text { comparative study on low } \\
\text { income women }\end{array}$ \\
\hline $\begin{array}{l}\text { Rote, S., \& Quadagno, J. } \\
\text { (2011) }\end{array}$ & $\begin{array}{ll}\text { - } & \text { ALPL } \\
\text { - } & \text { CHG } \\
\text { - } & \text { AEOJ } \\
\text { - } & \text { REEI }\end{array}$ & $\begin{array}{l}\text { - Quantitative study, } \\
\text { using data on welfare } \\
\text { recipient women ages 18- } \\
49 \text { years old }\end{array}$ \\
\hline Sardenberg, C. (2012) & $\begin{array}{ll}\text { - } & \text { ALPL } \\
\text { - } & \mathrm{CHG}\end{array}$ & $\begin{array}{l}\text { - Relevance of culture } \\
\text { to the promotion of gender } \\
\text { equality \& women's } \\
\text { empowerment. }\end{array}$ \\
\hline Smit, R. (2008) & $\begin{array}{ll}\text { - } & \text { ALPL } \\
\text { - } & \text { CHG } \\
\text { - } & \text { AEOJ }\end{array}$ & $\begin{array}{l}\text { Qualitative study; } 45 \\
\text { white sexually active } \\
\text { Afrikaans-speaking } \\
\text { married women. }\end{array}$ \\
\hline $\begin{array}{l}\text { Spiess, } \quad \text { C. } \quad \text { K. } \quad \text { \& } \\
\text { Dunkelberg, A. }(2009)\end{array}$ & $\begin{array}{ll}\text { - } & \text { CHG } \\
\text { - } & \text { ALPL } \\
\text { - } & \text { REP } \\
\text { - } & \text { AEOJ }\end{array}$ & $\begin{array}{l}\text { - Quantitative data of } \\
\text { mothers who gave birth to } \\
\text { a child in 2002, } 2003 \text { or } \\
2004 \text {. }\end{array}$ \\
\hline Stanley, S. (2012) & $\begin{array}{ll}\text { - } & \text { RFV } \\
\text { - } & \text { ALPL } \\
\text { - } & \text { AEOJ }\end{array}$ & $\begin{array}{l}\text { - Quantitative } \\
\text { comparative study } \\
\text { wives of alcoholics } \\
\text { India. }\end{array}$ \\
\hline Stanley, S. (2012) & $\begin{array}{ll}\text { - } & \text { RFV } \\
\text { - } & \text { ALPL }\end{array}$ & $\begin{array}{l}\text { - Quantitative } \\
\text { comparative study of } \\
\text { wives of alcoholics in }\end{array}$ \\
\hline
\end{tabular}




\begin{tabular}{|c|c|c|}
\hline & - $\quad$ AEOJ & India. \\
\hline $\begin{array}{l}\text { Stewart, M. J., Neufeld, } \\
\text { A., Harrison, M. J., } \\
\text { Spitzer, D., Hughes, K., \& } \\
\text { Makwarimba, E. (2006). }\end{array}$ & $\begin{array}{ll}\text { - } & \text { ALPL } \\
\text { - } & \text { AEOJ }\end{array}$ & $\begin{array}{l}\text { - Qualitative study on } \\
\text { low-income migrant } \\
\text { women family caregivers. }\end{array}$ \\
\hline
\end{tabular}

\section{Findings}

The findings will explore how the Grand Challenges and the SDGs are portrayed in current articles. We discuss the six Grand Challenges and the corresponding SDG in each section. The final section reviews the types of methods the articles used in collecting study data.

\subsection{Closing the Health Gap}

Of the articles found, 14 of them related directly to the Social Work Grand Challenge of closing the health gap. These 14 articles attempt to address the factors contributing to the health gap, particularly the health gap that exists for women. Pillai and Maleku (2013) recognize that women's health is much more vulnerable than men's health. One factor contributing to this is lack of quality food. This gap puts women at risk for several health issues such as maternal death and obesity (Phillips, 2009). Phillips (2009) recognizes the role that food security plays in poor health outcomes for women. The issue of food security is not limited to developing countries, but a problem that exists worldwide (Phillips, 2009).

Other themes that emerged in the literature were maternal health, reproductive health and mental health. Several articles discussed the poor health outcomes for women in these three areas (Jungari, 2015; Pillai \& Maleku, 2013; Pandey et al., 2012; Smit, 2008; Spiess \& Dunkelber, 2009; Rosen et al., 2006; Park et al., 2011; Price, 2010; Rote \& Quadagno, 2011; Grote et al., 2007). Price et al. (2011) cite lack of adequate accessible health care as a significant contributing factor to poor women's health across the globe. Other barriers highlighted in the literature include gender discrimination (Jungari, 2015), lack of women in decision-making positions (Pillai \& Maleku, 2013), and lack of education (Price, 2010).

\subsection{Stopping Family Violence}

Of the articles found, seven of them related directly to the Social Work Grand Challenge of ending family violence. One article specifically discusses female genital mutilation (Jungari, 2015); four discuss intimate partner violence in the Unites States (Macy et al., 2009), India (Pandey et al., 2012; Stanley, 2012), and Zambia (Klomegah, 2008); and two explore trafficking issues (Orme \& Ross-Sheriff, 2015; Hodge, 2014). While the literature focused on a small number of countries it was recognized that "Intimate partner violence is a global issue that transcends geographical boundaries and pervades all social strata" (Stanley, 2012). One study found that domestic abuse happens in about $84 \%$ of the 90 societies that were studied (Klomegah, 2008). Abuse by a partner results in both mental and physical health problems for women (Macy et al., 2009). Pandey et al. (2012) cite women's subordinate social status as the root cause of partner violence. Women's social status can be improved through education, knowledge relevant to sexually transmitted diseases, property rights, and access to public 
health services, which in turn would lead to a reduction in intimate partner violence and trafficking (Pandey et al., 2012, Orme \& Ross-Sheriff, 2015; Hodge, 2014). This grand challenge of social work echoes the UN sustainable development goals of ensuring health lives and prompting well-being for all and achieving gender equality and empowering all women and girls.

\subsection{Advancing Long and Productive Lives}

All 26 of the articles found related to the Social Work Grand Challenge of advancing long and productive lives by noting the barriers that currently prevent many women from living long and productive lives. These articles highlight barriers such as violence, poverty, economic inequality, lack of reproductive rights, poor mental health, and homelessness. While each article focuses on specific issues, the overarching theme of the articles is gender inequality. For example, Orme and Ross-Sheriff (2015) describe the issue of sex trafficking in the context of current efforts focused on the criminalization of policies, programs and services that could ultimately, target those seeking to purchase sexual services rather than the actual sex workers. However, they recognize that structural conditions of gender-based discrimination create an environment in which women are vulnerable. Several other articles touch on the significance of gender inequality and the role it plays in negatively affecting women's health. Many of the articles recognize the interconnectedness between barriers in place for women (Fawcett \& Reynolds, 2009). For instance, there are explorations about how food security is connected to women's health (Phillips, 2009) and how women's control of their reproductive health is connected to education, economic, and political participation of women (Alzate, 2009). Stewart et al., (2006) highlight the impact of caregiving on women's physical and mental health. In order to advance long and productive lives for women globally it is essential to acknowledge gender inequality and focus on the empowerment of women so that issues such as food security, accessing reproductive and mental health services, decreasing poverty rates, etc. can be more fully addressed (Orme \& Ross-Sheriff, 2015; Herbst, 2012).

\subsection{Ending Homelessness}

Of the articles found only one related directly to the Social Work Grand Challenge of ending homelessness (Park et al., 2011). This article focuses on the way in which poor mental health leads to homelessness as well as the ways in which homelessness contributes to poor mental health. The article points out that women are more likely to be living in poverty, which increases their likelihood of becoming homeless. According to Park et al. (2011) additional factors that influence and increase the risk for homelessness as well as maternal health problems consist of stressful life events and exposure to violence. Additionally, health problems appear to be more common among homeless mother than among other groups (Park et al., 2011). This article echoes the previous articles in saying that gender inequality contributes to poor health outcomes for women.

\subsection{Reducing Extreme Economic Inequality}

Of the articles found, eight of them related directly to the Social Work Grand Challenge of reducing extreme economic inequality. Each of these articles focused on the ways in which economic inequality leads to poor health outcomes for women. A number of the articles 
focused on mental health and found that women with low socioeconomic status were more likely to experience mental health issues (Grote et al., 2007; Rote \& Quadagno, 2011; Park et al., 2011; Rosen et al., 2006). Despite the increased rate of mental health needs among this population, it was found that women living in poverty were less likely to seek treatment for these issues (Grote et al., 2007). This issue is due in part to cost as well as accessibility of clinics (Grote et al., 2007). Grote et al. (2007) believe that a reduction of the number of women living in poverty would result in increased health for women. Economic development and improvements in income have shown to be a determinant of increased public health in low/middle income counties (Pillai \& Maleku, 2013). This grand challenge of social work is closely related to the SDG of ending poverty in all its forms everywhere and promoting sustained, inclusive and sustainable economic growth, full and productive employment and decent work for all.

\subsection{Achieve Equal Opportunity and Justice}

Of the articles found, 22 of them related directly to the Social Work Grand Challenge of achieving equal opportunity and justice. These articles vary in subject matter, with article topics including sex trafficking, food security, reproductive rights/health, partner violence, mental health, and poverty. These articles highlight many areas, which show that globally women are not given equal opportunities. Additionally, the articles summarize several social justice issues that impact women around the world.

Several of the articles recognize gender discrimination as the root cause of the inequality that exists (Orme \& Ross-Sheriff, 2015; Phillips, 2009; Pandey et al., 2011; Jungari, 2015). For example, Alzate (2009) recognizes that women's inability to control their own reproductive health contributes directly to their educational, political and economic opportunities. In addition, lack of equality contributes to practices such as sex trafficking (Orme \& Ross-Sheriff, 2015; Hodge, 2014), female genital mutilation (Jungari, 2015), partner violence (Klomegah, 2008), and overall poor health outcomes for women.

Several of the articles support the idea of empowering women in order to combat inequality and subsequent social justice issues (Fawcett \& Reynolds, 2009). For instance, Orme and Ross-Sheriff (2015) recognize empowerment as the key to addressing poverty across the globe. Pandey et al. (2011) state that women's empowerment is the basis for understanding maternal mortality rates. Themes emerged in many of the articles supporting the idea that the empowerment of women could help to decrease gender disparities and increase the health of women worldwide. This idea is supported by the SDG of achieving gender equality and empowering all women and girls. There is limited literature on ways cultures define women's empowerment. According to Sardenberg (2012), culture interacts and influences the development of movements relevant to women and it has been a crucial element for movements to go forward. She argues that culture is not a "crystallized entity," but rather a meaning that is constantly evolving especially in the context of gender equality and empowerment (2012).

\subsection{Populations Researched \& Methods Used}

The majority of the articles were either quantitative studies $(n=13)$ using data from secondary data sets or they were summaries $(n=11)$ emphasizing women's rights, linking to community 
capacity building, and exploring depression rates in women of color and/or low income. Only two of the studies used qualitative methods. For the two qualitative studies and five of the quantitative studies, the authors collected their own data in interactions with participants.

\section{Conclusion}

Social work as a profession needs to pay better attention to issues that affect women globally. This narrow view of how women should be researched does nothing for the profession and goes against our ethical obligation to engage in research that focuses on marginalized populations. As women's health continues to be in peril around the globe, it is imperative to address gender inequality to advance women's wellbeing and health. This article highlights the available literature exploring women's health globally. Through an ecofeminist lens the issues facing women are examined and connected to both the Grand Challenges of Social Work and the SDGs. Additionally, the articles highlight the interconnectedness among various issues facing women globally and highlights that by working towards closing the health gap, ending family violence, advancing long and productive lives, ending homelessness, reducing extreme economic inequality, and achieving equal opportunity and justice women's lives, and those of their children and families, can improve globally. In other words, this articles points to the social justice needs of women, as well as indicating that gender inequality is connected to economic equality, environmental inequality, educational inequality, etc. Many of the articles are summaries of the literature and what has been highlighted by others rather than conducting research on the topics linked to the Grand Challenges of Social Work - in addition, while using comparative data are useful the data need to be current (many of the comparative studies used data 10 to 15 years old and thus out of date).

Based on these findings, future research should include qualitative and quantitative data relevant to the health of women and that speak to each social work challenge and UN sustainable developmental goals. Through a feminist approach and social justice lens we get a sense of the dynamics of inequality and historical context. Additionally, future research should examine and tailor the UN sustainable developmental goals to the priorities, needs and resources of specific agencies or populations that helping professionals work with. This window of literature ultimate informs others about how interconnected and relevant current findings, exploring women's health globally, speak to how such area in literature has evolved.

\section{References}

Alzate, M. M. (2009). The role of sexual and reproductive rights in social work practice. Affilia, 24, 108-119. https://doi.org/10.1177/0886109909331695

Bird, M., Wright, R. L., \& Frost, C. J. (2016). Enhancing women's health: A call for social work research. Social Work In Health Care, 55, 732-751. https://doi.org/10.1080/00981389.2016.1205706

Craig, S. L., Bejan, R., \& Muskat, B. (2013). Making the invisible visible: Are health social workers addressing the social determinants of health? Social Work in Health Care, 52, 311-331. https://doi.org/10.1080/00981389.2013.764379

Eyal-Lubling, R., \& Krumer-Nevo, M. (2016). Feminist social work: Practice and theory of practice. Social Work, 61, 245-254. https://doi.org/10.1093/sw/sww026 


\section{Macrothink}

International Journal of Social Work ISSN 2332-7278

Fawcett, B., \& Reynolds, J. (2009). Mental health and older women: The challenges for social perspectives and community capacity building. British Journal of Social Work, 40, 1488-1502. https://doi.org/10.1093/bjsw/bcp042

Grote, N. K., Bledsoe, S. E. \& Larkin, J. (2007). Stress exposure and depression in disadvantaged women: The protective effects of optimism and perceived control. Social Work Research, 31, 19-33. https://doi.org/10.1093/swr/31.1.19

Grote, N. K., Zuckoff, A., Swatz, H., Bledsoe, S. E., \& Geibel, S. (2007). Engaging women who are depressed and economically disadvantaged in mental health treatment. Social Work, 52, 295-308. https://doi.org/10.1093/sw/52.4.295

Herbst, C. M. (2012). Footloose and fancy free? Two decades of single mothers' subjective well-being. Social Service Review, 86, 189-222. https://doi.org/10.1086/666390

Hodge, D. R. (2014). Assisting victims of human trafficking: Strategies to facilitate identification, exit from trafficking, and the restoration of wellness. Social Work, 59, 111-118. https://doi.org/10.1093/sw/swu002

International Federation of Social Workers (2012). Statement of ethical principles. Retrieved from http://ifsw.org/policies/statement-of-ethical-principles/

Jang, S. J. (2009). Global women's movements and Korean gender policy discourse. International Social Work, 52, 831-835. https://doi.org/10.1177/0020872809342661

Jayasooria, D. J. (2016). Sustainable development goals and social work: Opportunities and challenges for social work practice in Malaysia. Journal of Human Rights and Social Work, 1, 19-29. https://doi.org/10.1007/s41134-016-0007-y

Jungari, S. B. (2015). Female genital mutilation Is a violation of reproductive rights of Women: Implications for Health Workers. Health Social Work Health \& Social Work, 41, 25-31. https://doi.org/10.1093/hsw/hlv090

Klomegah, R. (2008). Intimate partner violence (IPV) in Zambia: An examination of risk Factors and gender perceptions. Journal of Comparative Family Stuides, 39, 557-569.

Ludwig, T. (2016). The key to engaging with the SDGS: Utilizing Rio principle 10 to successfully implement the U.N. sustainable development goals. Sustainable Development Law \& Policy, 16, 26-48.

Macy, R. J., Ferron, J., \& Crosby, C. (2009). Partner violence and survivors' chronic health problems: Informing social work practice. Social Work, 54, 29-43. https://doi.org/10.1093/sw/54.1.29

Mies, M., \& Shiva, V. (1993). Ecofeminism. Halifax, N.S.: Fernwood Publications.

Mortimer-Sandilands, C. (1999). The good-natured feminist: Ecofeminism and the quest for democracy. Minneapolis: University of Minnesota Press.

National Association of Social Workers (n.d.). Global health. Retrieved from https://www.socialworkers.org/practice/intl/issues/globalhealth.asp

Orme, J., \& Ross-Sheriff, F. (2015). Sex trafficking: Policies, programs, and services. Social Work, 60, 287-294. https://doi.org/10.1093/sw/swv031

Pandey, S., Lama, G., \& Lee, H. (2011). Effect of women's empowerment on their utilization of health services: A case of Nepal. International Social Work, 55, 554-573. 
https://doi.org/10.1177/0020872811408575

Pandey, S., Lin, Y., Collier-Tenison, S., \& Bodden, J. (2012). Social factors determining the experience of blindness among pregnant women in developing countries: The case of India. Health \& Social Work, 37, 157-169. https://doi.org/10.1093/hsw/hls025

Park, J. M., Fertig, A. R., \& Metraux, S. (2011). Changes in maternal health and health behaviors as a function of homelessness. Social Service Review, 85, 565-585. https://doi.org/10.1086/663636

Phillips, R. (2009). Food security and women's health: A feminist perspective for international social work. International Social Work, 52, 485-498. https://doi.org/10.1177/0020872809104252

Pillai, V. K., \& Maleku, A. (2013). Reproductive health and social development in developing countries: Changes and interrelationships. British Journal of Social Work, 45, 842-860. https://doi.org/10.1093/bjsw/bct168

Price, S. K. (2010). Women's use of multisector mental health services in a community-based perinatal depression program. Social Work Research, 34, 145-155. https://doi.org/10.1093/swr/34.3.145

Rosen, D., Warner, L. A., \& Tolman, R. M. (2006). Comparing psychiatric service use among low-income women and women in a general household population. Social Work Research, 30, 223-232. https://doi.org/10.1093/swr/30.4.223

Rote, S. \& Quadagno, J. (2011). Depression and alcohol dependence among poor women: Before and after welfare reform. Social Service Review, 85, 229-245. https://doi.org/10.1086/660679

Sardenberg, C. (2012). Negotiating culture in the promotion of gender equality and women's empowerment in Latin America. IDS Working Paper, 3-37. https://doi.org/10.1111/j.2040-0209.2012.00407.x

Smit, R. (2008). HIV and AIDS: Are all women equally at risk? Afrikaans speaking married women's perceptions of self-risk. Journal of Comparative Family Studies, 39, 413-428.

Spiess, C. K., \& Dunkelberg, A. (2009). The impact of child and maternal health indicators on female labor force participation after childbirth: Evidence for Germany. Journal of Comparative Family Studies, 40, 119-138.

Stanley, S. (2012). Intimate partner violence and domestic violence myths: A comparison of women with and without alcoholic husbands (a study from India). Journal of Comparative Family Studies, 43, 647-672.

Stewart, M. J., Neufeld, A., Harrison, M. J., Spitzer, D., Hughes, K., \& Makwarimba, E. (2006). Immigrant women family caregivers in Canada: Implications for policies and programmes in health and social sectors. Community Health and Social Care in the Community, 14, 329-340. https://doi.org/10.1111/j.1365-2524.2006.00627.x

United Nations (n.d.). Sustainable Development Goals. Retrived from https://sustainabledevelopment.un.org/?menu=1300

Warren, K. (2002). Ecofeminist philosophy: A Western perspective on what it is and why it matters. Lanham, MD: Rowman \& Littlefield. 


\section{Macrothink}

International Journal of Social Work

ISSN 2332-7278 2016, Vol. 3, No. 2

Warren, K., \& Erkal, N. (1997). Ecofeminism: Women, culture, nature. Bloomington: Indiana University Press.

Williams, J. H. (2016). Grand Challenges for Social Work: Research, practice, and education. Social Work Research.

Wright, R. L., Bird, M., \& Frost, C. J. (2015). Reproductive health in the United States: What is included in the recent social work literature. Social Work 60, 295-304. https://doi.org/10.1093/sw/swv028

\section{Copyright Disclaimer}

Copyright reserved by the author(s).

This article is an open-access article distributed under the terms and conditions of the Creative Commons Attribution license (http://creativecommons.org/licenses/by/3.0/). 